\title{
Ethnomedicine of Wild Plants of Ziro, Arunachal Pradesh
}

\author{
Victor Singh Ayam
}

Department of Botany, Rajiv Gandhi University, Doimukh, Arunachal Pradesh-791112

\begin{abstract}
:
Background: Ethnomedicinal study of wild plants and the threats to them was conducted at Ziro, Arunachal Pradesh, India. The objective of the study was to identify and document wild plants, the associated ethnobotanical knowledge of the local people and the threats that exist to the plants.

Materials and Methods: Ethnomedicinal data on wild edible fruits were collected using a guided methodology, semi-structured interviews, and field observations. The information was verified by cross-checking it among the informants. Descriptive statistics and pairwise ranking of threat factors were employed to gather the ethnobotanical data.

Results: We documented 30 wild plants distributed in 28 genera and 22 families based on local claims of use as medicine. Most of them are dicots, 3 monocots and 2 pteridophytes. The common families that encompass more number of wild medicinal plant species were Asteraceae and Solanaceae (four species each), followed by Berberidaceae and Lauraceae(two species), and the remaining 18 families contributed one species each.

Conclusion: The study showed the existence of wild medicinal plants that act asailments of different disease. The informants stated that wild medicinal plants are threatened due to increased anthropogenic pressure, some of which are under the "IUCN Red List of Threatened Species", enlist as "Endangered" and "Least Concern" categories. This calls for urgent and collaborative action to keep the balance between medicinal plant availability in the wild and their utilisation by the community. The results of this study also indicate that carrying out subsequent pharmacological and phytochemical investigations on these wild fruits could lead to new drug discoveries.
\end{abstract}

Keywords: medicinal importance, relative frequency of citation, use value, wild fruits, household consumption

\section{INTRODUCTION}

Plants have been the basis of life on earth and are the main source of livelihood since time immemorial. The interaction with the plants varies with different geographical locations and the ethnic community. This study of the plants in relation to their use by the people of particular community is a branch of the botany known as Ethnobotany. Since the time immemorial many plants were grown wild in the Lower Subansiri district of Arunachal Pradesh. These plants have been the important part of the local people. Some of the wild plants have even become an important part of the culture in some indigenous people's tradition and are known to be effective against certain diseases thus getting popular and commercialized into various products [1]. This diversity of wild medicinal plants is attributed to a wide range of altitude, the existence of the diverse climatic conditions ranging from tropical to temperate vegetation. Many of the wild plants even constitute the important part of the sacred grooves in Ziro. The Apatani tribe of Ziro is known to use different plant species for healing different diseases. These traditional medicines are practiced because of their easy availability of raw materials, effectiveness without side effects, and affordability.However, urbanisation and change in lifestyle causes people drifting away from these age-old practices and it may lead to a decline in the traditional knowledge about wild medicinal plants. With the very few reports on medicinal plants from this region there is a high possibility of losing TKS as a whole from this region. Therefore, the present study aimed at documenting and preserving the indigenous knowledge of wild medicinal plants use by the Apatanis of Ziro, Arunachal Pradesh.

\section{MATERIALS AND METHODS}

\subsection{Study Site}

The field investigation was conducted extensively in Ziro of Lower Subansiri district, Arunachal Pradesh from June 2012 - October 2014, and encompassed different wildmedicinal plants. The study 
site, Lower Subansiri district of Arunachal Pradesh, has a population of 83,030, in 652 villages, with a population density of 42 individuals per sq. $\mathrm{km}$. (Census, 2011) [2]. The district covers an area of $3508 \mathrm{~km}^{2}$ within the geographical coordinates of $26^{\circ} 55^{\prime}$ and $28^{\circ} 21^{\prime} \mathrm{N}$ and $92^{\circ} 40^{\prime}$ and $94^{\circ} 21^{\prime} \mathrm{E}$, at an altitude of 1500 to $2750 \mathrm{~m}$ above sea level, bordered by West Siang and part of Upper Subansiri in the east, Kurung-Kumey and Upper Subansiri districts in the north, Papum Pare district of Arunachal Pradesh and Assam in the south and portions of Kurung-Kumey and Papumpare districts in the west. The whole territory of this district is mostly mountainous and is surrounded by various hill ranges.Ziro, the district head quarter of Lower Subansiri district located at $26^{\circ} 55^{\prime}-28^{\circ} 21^{\prime} \mathrm{N}$ latitude and $92^{\circ} .40^{\prime}-94^{\circ} 21^{\prime} \mathrm{E}$ longitude is at an elevation of 2200 meters (Fig.1). The climate of Ziro is characterized by high humidity throughout the year. The average annual rainfall of Ziro was 934.88 $\mathrm{cm}$ during 2000. Most of the Apatanis are loyal followers of the Danyi-Piilo faith, who pray to the sun (Ayo Danyi) and the Moon (Atoh Piilo). In olden days, the Apatani had prominent tattoo marks on the face to distinguish themselves from other communities settled nearby. Also says that it was to avoid other dominating tribes capturing their women folks. However, the practice of tattooing has been discouraged in the recent past and now is on the verge of extinction (Fig 2A, Fig 2B).A humid subtropical to the temperate type of climate and high and low temperatures of $30.6^{\circ} \mathrm{C}$ and $1.1^{\circ} \mathrm{C}$ with $108.1 \mathrm{~cm}$ average rainfall $[3,4]$ have shaped the two major vegetation types in and around the study area namely i) sub-tropical forests and ii) temperate forests.

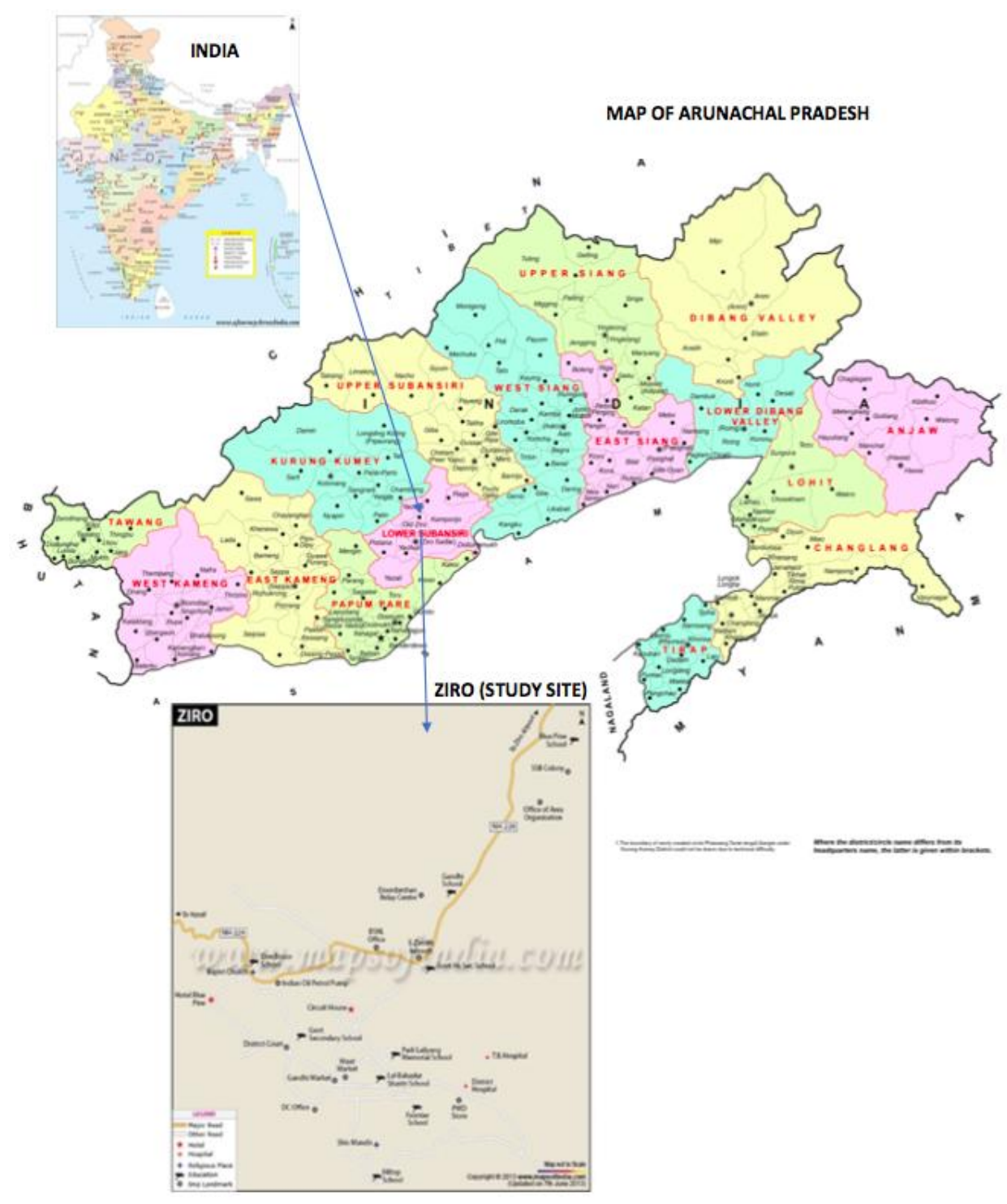

Fig1. Map showing the location of Ziro, Arunachal Pradesh

FIG 1(A) Map of India (showing the location of Arunachal Pradesh), Fig 1(B). Map of Arunachal Pradesh (one of the states of India), Fig 1(C). Map of the study site, Ziro (one of the districts of Arunachal Pradesh. 


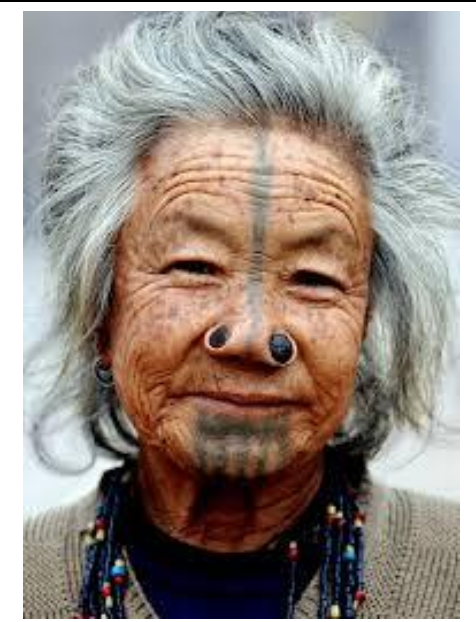

Figure1. Facial Tattoo of Apatani

Fig2A. Apatani Woman

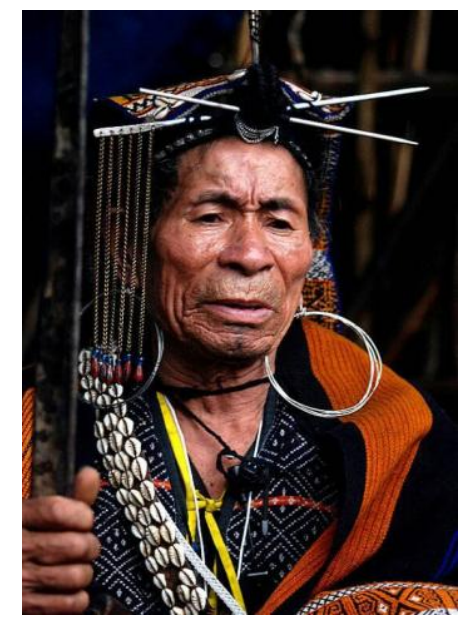

Fig2B. Apatani man

\subsection{Plant Specimen Collection and Identification}

For ethical reasons, ethnobotanical data were collected with the prior approval and permission of the local administrator (Village Head) and the informants for publication of the research. Good specimens (with flowers and/or fruits) of all the wild edible fruit plants identified by the local guides were collected as voucher specimens during field walks following a guided methodology (Jain SK and Rao RR, 1977) [5]. Each specimen was given a collection number along with a scientific and/or local name when possible. The information was also captured in photographs of the sites, individual plants, and their flowers and fruits. The plant specimens were pressed, and herbarium voucher specimens were prepared following chemical sterilisation. Identification of the specimens was done according to the literature, "Flora of British India" [6], referring to specimens in Botanical Survey of India (BSI, Arunachal Pradesh), and classified following Bentham and Hooker's classification system.

\subsection{Data Collection}

The objective of the study was clearly explained to the participants (local informants). A questionnaire containing a prior informed consent (PIC) developed following the method of Edwards et al. [7] was signed by an informant before an interview was conducted. The informants from 35 to 70 years of age including traditional healers were interviewed on the local household use of wild plants as medicine and recipes for the preparation.

\subsection{Validation and Reliability of the Data}

A consensus of the informants was used to validate the reports, to identify the plants most cited by the informants and also the information gathered was compared and cross-checked with the help of group discussions among different age classes of Apatani villagers that include both the genders of the society. 


\section{RESULTS AND DISCUSSION}

Altogether 30 wild medicinal plants belonging to 28 genera and 22 families are reported based on local claims of use as medicine. Most of them are dicots (25), 3 monocots and 2 pteridophytes. The families that have the highest number of wild medicinal plant species were Asteraceae and Solanaceae (four species each), followed by Berberidaceae and Lauraceae(two species), and the remaining 18 families contributed one species each. The 30 species were reported to cure 10 different types of diseases during the study. Maximum plants species (06) were found touse against cough. The above ground plant parts (leaf and fruits) wereused more than the underground plant parts (root, tuber, rhizome, bulb, etc.).

\subsection{Following are the medicinal plants collected during the study. References [8-14]}

\section{Ageratum conyzoides Linn.}

Family: Asteraceae

Vernacular Name: Borba Tami

Description: Annual herb, stem erect, hairy green or purple, leaves opposite with hairs. Inflorescence terminal.

Habitat: Common weeds and is cosmopolitan in distribution.

Propagation: By seeds

Part used: Leaves

Uses: Leaf juice, leaf paste is applied to cuts, wounds to stop bleeding. It is used as a first aid.

\section{Allium schoenoprasum}

Family: Liliaceae

Vernacular name: Lepli/Talley

Description: An annual herb growing from a bulb. Numerous long and narrow leaves emerge from the base. The bulbs are covered with long, thin membranous sheath.

Habitat: Cultivated

Propagation: Seeds

Part used: Leaves and roots

Uses: Leaves and roots are used as vegetable and as anthelmintic. It is also good for massaging during body ache, improves blood circulation, antiseptic property, digestion.

\section{Artimesia indica}

Family: Asteraceae

Vernacular name: Kukulyu

Description: A tall erect perennial herb. Leaves are bipinnatifid, green on the upper side and silvery below. Fruit is a dark brown to black coloured achene.

Habitat: Dry area of Ziro

Propagation: Seeds

Part used: Aerial shoots, leaves

Uses: Fomentation by leaves given relief in headache.

\section{Acorus calamus}

Family: Araceae

Vernacular name: Kiile Tolyo

Description: A perennial semi-aquatic herb with aromatic rhizomes. Leaves are slender, erect, sword like and bright green with a distinct midrib. Green coloured flowers appear in 2-4 spadices below the leaf tips. Fruits are small berries. 
Habitat: Swampy areas of Ziro

Propagation: Rhizomes

Part used: Dried rhizomes

Uses: applied on wounds for quick healing.

\section{Berberis aristata}

Family: Berberidaceae

Vernacular name: Tiipe Tiirey

Description: An erect spiny shrub. It is a woody plant, with bark that appears yellow to brown from the outside and deep yellow from the inside. The leaves are simple with pinnate venation. The leaves are leathery in texture and are toothed with several too many small indentations along the margin of the leaf.

Habitat: Dry and muddy area

Propagation: By seeds

Part used: Stem, Roots, Fruit

Uses: It has a antibacterial, Antifungal, Antiviral, Antioxidant and Anti-diabetes properties. Spines are used for tattooing on chin and forehead.

\section{Centella asiatica}

Family: Umbelliferae

Vernacular name: Ngilyang Khiiko

Description: Small trailing herb, stem slender, creeping stolons, green to reddish green in colour.

Habitat: Muddy area/wet area.

Propagation: Seeds

Part used: Whole plant

Uses: It is used in the treatment of stomach trouble, Antiulcerogenic, cerebral tonic.

\section{Clerodendrum colebrookianum}

Family: Verbenaceae

Vernacular name: Pato Hamang

Description: It is a shrub. Leaves are simple, opposite or rarely whorled. Leaf base is heart shaped, flowers are white and borne in 4-6 branched corymbose cymes, at the end of branches

Habitat: Dry area

Propagation: Seeds

Part used: Leaves

Uses: It is used for control of high blood pressure

\section{Dioscorea bulbifera}

Family: Dioscoreaceae

Vernacular name: Hula

Description: A vigorously twining annual vine. Leaves are alternate with long stalk, broadly cordate with rounded basal lobes. Flowers are small. Fruit is a capsule. Arial potato-like bulbils are borne at the base of the leaf axil.

Propagation: Bulbils

Part used: Tubers

Uses: Pounded tubers are rubbed on spots with burning sensation. 


\section{Cinnamomum zeylanicum}

Family: Lauraceae

Vernacular name: Niikhe

Description: It is a evergreen tree with 20-25 ft. tall. Leaves are frontal, leathery, the upper part is shiny with 3-5 veins. Flowers are long and grow in branches. Propagation: Seeds

Part used: Bark and roots

Uses: It has a digestive properties, it is also used in the treatment of cough.

\section{Equisetum arvense}

Family: Equisetaceae

Vernacular name: Ami Tiiper

Description: A rigid perennial rhizomatous herb. Stems are hollow with distinct nodes having sterile and fertile stems. Sterile stems are taller than the fertile ones. Leaves are small scales which are fused into sheaths.

Propagation: Vegetative propagation, spores.

Part used: Whole plant

Uses: It is used in the treatment of rheumatism and arthritic problems, coughing.

\section{Houttuynia cordata}

Family: Saururaceae

Vernacular name: Siya Hamang

Description: A perennial herbaceous aromatic plant commonly found in open

fields. Leaves are alternative, pubescent and heart-shaped. Flowers are white

Habitat: Grow in wet places

Propagation: By seed and vegetative method

Part used: Whole plant

Uses: Locally used for treatment of dysentery, stomach pain, Digestion, it is also considered as effective for providing good sleep.

\section{Litsea citrata}

Family: Lauraceae

Vernacular name: Santero

Description: A medium sized deciduous tree. Leaves are lanceolate, ovate to oblong. Flowers are yellow in colour. Fruit is a berry and lemon scented

Propagation: Seed

Part used: Seeds

Uses: It is a pain reliever and also considered as effective for providing good sleep.

\section{Lycopodium $s p$}

Family: Lycopodiaceae

Vernacular name: Sibi lyai

Description: It is widely branched, erect, prostrate or creeping stems, with small, simple, needle-like or scale-like leaves that covers the stem and branches thickly.

Propagation: Spores and vegetatively through above or below ground rhizomes.

Habitat: Dry area

Part used: Whole plant

Uses: Treatment of anti-cancer 


\section{Lycopersicon lycopersicum}

Family: Solanaceae

Vernacular name: Mudo Byayung

Description: An annual pubescent herb. Leaves are irregularly pinnate, hairy and serrated. Flowers are yellow. Fruits are small and red in colour when ripe.

Propagation: Seeds

Habitat: Dry and Muddy area

Part used: Fruits

Uses: It prevents breast cancer, reduces cardiovascular risk.

\section{Melastoma malabathricum}

Family: Melastomataceae

Vernacular name: Pepu Yoyu

Description: A perennial large bushy shrub. Leaves are opposite, hairy above and scaly below. Flowers are purple in colour. Fruit is a purple coloured

berry like capsule with numerous seeds.

Propagation: By seeds

Habitat: Dry area

Part used: Flowers and leaves, fruits

Uses: It is used in the treatment of Jaundice

\section{Mahonia nepalensis}

Family: Berberidaceae

Vernacular name: Taming

Description: A perennial thorny shrub. Leaves are compound, alternate, shiny and spiny on the margin. Flowers are in axillary and terminal racemes and yellow in colour. Fruit is a berry and are purplish blue in colour when matured.

Propagation: Seeds

Habitat: Dry area

Part used: $2^{\text {nd }}$ layer bark of yellow portion

Uses: Toothache, Removable of dental worm

\section{Myrica esculenta}

Family: Myricaceae

Vernacular name: Baching

Description: A medium sized sub-tropical evergreen deciduous tree. Leaves are opposite, lanceolate and dentate. Flowers are small, fruit is a succulent drupe, globose and red in colour.

Propagation: By seeds

Part used: Fruits

Uses: Antiseptic and Astringent

\section{Michelia champaca}

Family: Magnoliaceae

Vernacular name: Salyo

Description: A large evergreen tree. Leaves simple, flowers are pale yellow to orange. Fruit is made up of up to 3-20 brown follicles that are dry at maturity and split open at one side. Each follicle contains 2-6 reddish seeds 
Propagation: Seeds

Part used: Fruits

Uses: It is used in the treatment of constipation, Digestive, Stomach problems.

\section{Mikania micrantha}

Family: Asteraceae

Vernacular name: Man Tami

Description: A branched, slender stemmed perennial vine. The leaves are arranged in opposite pairs along the stem and are heart shaped or triangular with an acute tip and a broad base. Flowers 3-5 mm long, are arranged in dense terminal or axillary corymbs. The seed is black, linear-oblong, five-angled and about $2 \mathrm{~mm}$ long.

Propagation: Seeds and vegetatively by rooting at nodes.

Part used: Stem and leaves

Uses: Juice of stem and leaves are applied in skin diseases, itching and skin allergy. Leaf juice is also used for healing of wounds, also used in cuts to stop bleeding.

\section{Mimosa pudica}

Family: Fabaceae

Vernacular name: Hiiyang Tami

Description: A woody perennial trailing plant, stems and branches are covered with sparse or dense prickle. Leaves are bipinnately compound with 10-26 leaflets per pinnae, the leaves are very sensitive to touch. Flowers are pink or purple in colour and are produced at the leaf axil. Fruit is a flat and hairy pod containing pale brown seeds.

Propagation: By seeds

Part used: Leaves and roots

Uses: It is used in treating pile problems, skin diseases.

\section{Oxalis corniculata}

Family: Oxalidaceae

Vernacular name: O-Khui hamang

Description: An annual herbaceous plant with creeping stems that produces root at the nodes. Leaves are clover-shaped trifoliolate. Solitary flowers are yellow in colour. Fruits is a capsule, 5-angled and seeds are brown in colour, numerous and broadly ovoid in shape.

Propagation: By seeds

Part used: Whole plant

Uses: Whole plant (raw/boiled) are used as vegetable to promote appetite; plant juice is applied on cuts and injuries to stop bleeding; dysentery, diarrhea.

\section{Piper longum}

Family: Piperaceae

Vernacular name: Riidii

Description: A slender aromatic climber with perennial woody roots. Leaves are ovate-oblong, fruits are ovoid in shape and yellowish-orange in colour.

Habitat: Dry and shade area

Propagation: Seeds

Part used: Fruit and roots.

Uses: roots are chewed as a remedy for cough, asthma, dysentery. 


\section{Rubus ellipticus}

Family: Rosaceae

Vernacular name: Nyinkhe jilying

Description: A large shrub with stems and branches covered with prickles and reddish hairs. Leaves are alternate and compound with three elliptic or obovate leaflets. Flowers are white. Fruits are orange to yellowish in colour and are soft and juicy.

Propagation: Seeds

Part used: fruits

Uses: The juice of fruit is used in the treatment of fever, cough and sore throat

\section{Ranunculus diffuses}

Family: Ranunculaceae

Vernacular name: Yapung gelung

Description: A small perennial herb with fibrous roots where stem roots at lower nodes. Leaves are 3partite or 3-sect. with cordate base. Flowers are yellow in colour. Fruits are flat achene and broadly elliptic or obovate in shape.

Propagation Seeds

Part used: Roots, stems

Uses: Root paste is applied to cuts and wounds root juice is taken to treat stomachache.

\section{Solanum khasianum}

Family: Solanaceae

Vernacular name: Siitii Byako

Description: A short prickly perennial shrub with several branches. Leaves are base cordate tapering towards the end, irregularly lobed, pubescent with stiff long hairs and prickly on both the surfaces of the leaves. Flowers are white in colour. Fruits is globose, variegated with white and green colour, fleshy with numerous small seeds.

Habitat: Dry area

Propagation: Seeds

Part used: Fruit

Uses: Treatment of dental worms, and leach protection

\section{Solanum indicum}

Family: Solanaceae

Vernacular name: Misang byako

Description: A prickly undershrub with hairy and prickly stem. Leaves are simple, irregularly lobed and sparsely prickly. Flowers are blue in colour and occur at the tip of lateral branches on cymose raceme. Fruit is berry, globose, green turning red or dark yellow when ripe. Seeds are minute.

Propagation: Seeds

Habitat: Dry area

Part used: Fruits

Uses: It is used against constipation and any stomach problem.

\section{Solanum nigrum}

Family: Solanaceae

Vernacular name: Hiiro byako 
Description: An annual herb. Leaves are ovate to lanceolate with irregular margin. Flowers are white. Fruit is berry like green in colour which turns black when ripe.

Habitat: Dry area

Propagation: Seeds

Part used: Fruits and leaves

Uses: It is used for the treatment of low blood pressure, dysentery, stomach problem. The leaves improve appetite.

\section{Spilanthes paniculata}

Family: $s$

Vernacular name: Yorkhung hamang

Description: An annual or short-lived perennial herb and rooting at the nodes. Leaves opposite, simple, mostly dentate and flowers heads are conical or radiate.

Habitat: Muddy area

Propagation: Seeds and vegetatively by rooting at nodes.

Part used: Leaves and stems

Uses: It is used as an appetizer and for curing intestinal worms. Leaves are used as a condiment or eaten raw/boiled to remove constipation. Flower paste is applied or chewed in case of toothache.

\section{Zingiber officinale}

Family: Zingiberaceae

Vernacular name: Taki

Description: A slender, perennial rhizomatous herb, leaves linear, sessile, Rhizomes white to yellowish brown in colour.

Habitat: Muddy area

Propagation: By rhizome

Part used: Rhizome, leaves, stems

Uses: It is used in the treatment of cough, antiseptic, anti-inflammatory.

\section{Zanthoxylum armatum}

Family: Rutaceae

Vernacular name: Yarkhung

Description: A perennial prickly deciduous woody shrub. Leaves are pinnate having wings on both sides of the petiole. Flowers are yellowish to green colour. Fruits are sub-globose and red in colour.

Propagation: Seeds

Part used: Fruit/Seeds

Uses: The seed powder with equal amount of salt is used against cold, cough and fever; also given to increase appetite.

\section{Medicinal Plants used for the Treatment of Various Ailments}

Plants used for the treatment of cough

\begin{tabular}{|c|c|c|c|c|}
\hline Sl. No. & Scientific Name & Local name & Parts use & Family \\
\hline 1. & Cinnamomum zeylanicum & Niikhe & Bark \& roots & Lauraceae \\
\hline 2. & Equisetum arvense & Ami Tiiper & Whole plant & Equisetaceae \\
\hline 3. & Piper longum & Riidii & Fruits \& roots & Piperaceae \\
\hline 4. & Rubus ellipticus & Nyinkhe jilying & Fruits & Rosaceae \\
\hline 5. & Zingiber officinale & Taki & Whole plant & Zingiberaceae \\
\hline 6. & Zanthoxylum armatum & Yarkhung & Fruits/seeds & Rutaceae \\
\hline
\end{tabular}


Plants used for the treatment of Jaundice

\begin{tabular}{|c|c|c|c|c|}
\hline Sl. No. & Scientific Name & Local name & Parts used & Family \\
\hline 1. & Melastoma malabathricum & Pepu yoyu & Flowers, fruits \& leaves & Melastomataceae \\
\hline
\end{tabular}

Plants used for the treatment of Dysentery

\begin{tabular}{|c|c|c|c|c|}
\hline Sl. No. & Scientific Name & Local Name & Parts used & Family \\
\hline 1. & Houttuynia cordata & Siya Hamang & Whole plant & Saururaceae \\
\hline 2. & Oxalis corniculata & O-Khui hamang & Whole plant & Oxalidaceae \\
\hline 3. & Piper longum & Riidii & Fruits \& roots & Piperaceae \\
\hline 4. & Solanum nigrum & Hiiro byako & Fruits \& leaves & Solanaceae \\
\hline
\end{tabular}

Plants used for the treatment of blood pressure

\begin{tabular}{|c|c|c|c|c|}
\hline Sl. No. & Scientific Name & Local Name & Parts used & Family \\
\hline 1. & Clerodendrum colebrookianum & Pato hamang & Leaves & Verbenaceae \\
\hline 2. & Solanum nigrum & Hiiro byako & Fruits \& leaves & Solanaceae \\
\hline
\end{tabular}

Plants used for the treatment of cancer

\begin{tabular}{|c|c|c|c|c|}
\hline Sl. No. & Scientific Name & Local Name & Parts used & Family \\
\hline 1. & Lycopodium Sp. & Sibi lyai & Whole plants & Lycopodiaceae \\
\hline 2. & Lycopersicon lycopersicum & Mudo byayung & Fruits & Solanaceae \\
\hline
\end{tabular}

Plants used for the treatment of toothache/dental worms

\begin{tabular}{|c|c|c|c|c|}
\hline Sl. No. & Scientific Name & Local Name & Parts Used & Family \\
\hline 1. & Centella asiatica & Ngilyang khiiko & Whole plant & Umbelliferae \\
\hline 2. & Houttuynia cordata & Siya hamang & Whole plant & saururaceae \\
\hline 3. & Michelia champaca & Salyo & Fruits & Magnoliaceae \\
\hline 4. & Ranunculus diffuses & Yapung gelung & Stem, roots & Ranunculaceae \\
\hline 5. & Solanum indicum & Misang byako & Fruits & Solanaceae \\
\hline 6. & Solanum nigrum & Hiiro byako & Fruits , leaves & solanaceae \\
\hline
\end{tabular}

Plants used for the treatment of stomach problems

\begin{tabular}{|c|c|c|c|c|}
\hline Sl. No. & Scientific Name & Local Name & Parts used & Family \\
\hline 1. & Mahonia nepalensis & Taming & $\begin{array}{c}2^{\text {nd }} \text { layer of bark of yellow } \\
\text { portion }\end{array}$ & Berberidaceae \\
\hline 2. & Solanum khasianum & Siitii Byako & Fruits & Solanaceae \\
\hline 3. & Spilanthes paniculata & Yorkhung hamang & Leaves and stems & Asteraceae \\
\hline
\end{tabular}

Plants used for the treatment of skin disease

\begin{tabular}{|c|c|c|c|c|}
\hline Sl. No. & Scientific Name & Local Name & Parts Used & Family \\
\hline 1. & Mikania micrantha & Man Tami & Stem and leaves & Asteraceae \\
\hline 2. & Mimosa pudica & Hiiyang Tami & Leaves and roots & Fabaceae \\
\hline
\end{tabular}

Plants used for the treatment of headache

\begin{tabular}{|c|c|c|c|c|}
\hline Sl. No. & Scientific Name & Local Name & Parts Used & Family \\
\hline 1. & Artimesia indica & Kukulyu & Aerial shoots and leaves & Asteraceae \\
\hline
\end{tabular}

Plants used for the treatment of body ache

\begin{tabular}{|l|l|l|l|l|}
\hline Sl. No. & Scientific Name & Local Name & Parts Used & Family \\
\hline 1. & Allium schoenoprasum & Lepi/Talley & Leaves and roots & Liliaceae \\
\hline
\end{tabular}

\section{Conclusion}

Above finding sows the dominance of Asteraceae and Solanaceae families in its potential as medicinal and curing of diseases in the region. For many centuries, the Apatani had kept alive a selfmanaged system of folk medicine that was mainly based on herbal remedies. However, several factors including infrastructural development projects, firewood collection, human habitation, cash crops mono cultural practices, shifting cultivation and rarely by forest firing cause a decrease in the plant population. In our collection two species were under The IUCN Red List of Threatened Species as Least Concerned category such as Mimosa pudicaandMagnolia champaca $[15,16]$. Therefore, a need for conservation arises while utilizing of not caring the plants at the sometime the claimed medicinal properties of these natural resources need to be checked, and further analysisis required in order to develop the potential herbal medicine. 


\section{REFERENCES}

[1] Prakash D, Upadhyay G, Gupta C, Pushpangadan P and Singh KK: Antioxidant and free radical scavenging activities of some promising wild edible fruits. International Food Research Journal, 2012. 19(3):1109-1116.

[2] Census of India, District Census Handbook Lower Subansiri district, village and town wise primary census abstract (PCA), Directorate of Census Operations, Arunachal Pradesh, 2011. http://www.censusindia.gov.in/2011census/dchb/1207 Retrieved 2011-09-30.

[3] Ground water information. Booklet Lower Subansiri district, Arunachal Pradesh. Central Ground Water Board, North East Region, Ministry of Water Resources. Guwahati. 2013.

[4] Saikia SK, Das DN. 'Aji gnui asonii'- a practice of organic hill farming among the Apatani tribe of Eastern Himalaya. International Journal of Sustainable Development and World Ecology 2004, 11:211-217.

[5] Jain SK, Rao RR. A Handbook of Field and Herbarium Technique. Today and Tomorrow Publication, New Delhi, 1977.

[6] Hooker JD. Flora of British India 1871-97, Vol.1-7, London. (Reprinted in 1982 by Bishen Singh Mahendra Pal Singh, Dehra Dun, Vols. I-VII).

[7] Edwards S, Nebel S, Heinrich M. Questionnaire surveys: methodological and epistemological problems for field-basedethnopharmacologists. Journal of Ethnopharmacology. 2005, 100(1):3036.

[8] Baruah, M. and D.Kalita. Ethnomedicine used by mishing tribes of Dibrugarh District, Assam, Indian Journal of traditional knowledge Vol.6(9) Oct.2007, pp595-598.

[9] Bhardwaj, S. and S.K. Gakhar: Ethnomedicinal plants used by the tribals of Mizoram to cure cuts and wounds. Indian Journal of Traditional knowledge 2005, 4(1), pp.75-80.

[10] Bradacs,G;Heilmann,J; Weckerle,C.S (Institute of Anatomy, University of Zurich, Winterthurerstrasse 190, 8057 Zurich, Switzerland). Medicinal plants use in Vanuatu: a comparative ethnobotanical study of three islands. Journal of Ethnopharmacology, V.137 (I):P,434-448, 2011 (Eng;53 ref).

[11] Chandra Prakash Kala. Ethnomedicinal botany of the Apatani in the Eastern Himalayan region of India, Journal of Ethnobiology and Ethnomedicine 2005, 1:11. doi:10.1186/1746-4269-1-11 (http://www.ethnobiomed.com/content/1/1/11).

[12] Choudhury, S., Choudhury, M.D, Sharma, G.D and Chetia, P.(2010) Ethnobotany and drug discovery: Experimental approach. In Medicinal Plants of northeast India (Ed) Borthakur, S.K., Ahmed, M., Gogoi,P.,Dutta,D.N. and Ahmed, G.U.Pp.220-234.

[13] Haridasan, K., G.P. Shukla and B.S Beniwal, 1995. Medicinal plants of Arunachal Pradesh, SFRI Publication. Itanagar, India.

[14] Kumar, S. 2002. The Medicinal Plants of North-East India.

[15] Groom, A. 2012. Mimosa pudica. The IUCN Red List of Threatened Species 2012:e. T175208A20112058. http://dx.doi.org/10.2305/IUCN.UK.2012.RLTS.T175208A20112058.en. Downloaded on 17 June 2017.

[16] Khela, S. 2014. Magnolia champaca. The IUCN Red List of Threatened Species 2014: e.T191869A15267603.http://dx.doi.org/10.2305/IUCN.UK.20143.RLTS.T191869A15267603.en a.Downloaded on 17 June 2017. 